\title{
A tápanyagellátás, a száraztömeg és a növényi K-tartalom összefüggései sörárpánál
}

\author{
BALÁZSY ÁGNES-SÁRDI KATALIN
}

Pannon Egyetem Georgikon Kar, Növénytermesztéstani és Talajtani Tanszék, Keszthely

\section{Összefoglalás}

A tápanyag-gazdálkodás továbbfejlesztéséhez szükséges a növények tápláltsági állapotát jól jellemző, valamint a várható terméssel minél megbízhatóbb kapcsolatot mutató tápelemkoncentrációk megállapítása. Ismert, hogy a kálium számos életfolyamat nélkülözhetetlen eleme a növény életében.

Dolgozatunk célja, hogy összefüggést keressünk a kijuttatott kezelések és a növény tápláltsági állapota között.

Tenyészedényes kísérletünket 2006 tavaszán üvegházi körülmények között állítottuk be agyagbemosódásos barna erdótalajon. Tesztnövénynek a tavaszi árpa (Hordeum vulgare L.) Scarlett fajtáját választottuk. A trágyázatlan kontrollon kívül nyolc NPK kezelést alkalmaztunk két NP szinten növekvő K-adagokkal. Különböző fejlettségi stádiumokban, fố növényi részenként folytattunk vizsgálatokat.

A legmagasabb K-koncentráció a bokrosodáskori növényekben mutatható ki, az általunk kijuttatott kezelések hatására mért legmagasabb K-koncentráció 6,6\% volt, melyet az $\mathrm{N}_{2} \mathrm{P}_{2} \mathrm{~K}_{3}$ kezelésnél kaptunk. A virágzó kalász K-tartalma a trágyázástól függetlenül közel azonosnak bizonyult, 0,81-0,90\% közé esik. A $\mathrm{K}_{0}$ kezelések kivételével az általunk mért K-koncentrációk a kielégítô, ill. magas kategóriába esnek. Az összefüggés-vizsgálatok eredményei igazolják, hogy szoros kapcsolat van a növény K-tartalma és száraztömeg-gyarapodása között. A különbözô adagú és arányú kezelések erôsen befolyásolják, hogy az egyes növényi részek különböző fejlettségi stádiumokban mekkora mennyiségben és milyen eloszlásban tartalmazzák a felvett K-ot, hogyan alakul száraztömegük, víztartalmuk.

Kulcsszavak: tenyészedényes kísérlet, NPK-trágyázás, tavaszi árpa, növényi produktum 


\title{
Correlations between nutrient supply, dry weight and plant $K$ content in malting barley
}

\author{
Á. BALÁZSY-K. SÁRDI \\ University of Pannonia, Georgikon Faculty of Agriculture, \\ Department of Crop Production and Soil Science, Keszthely
}

\begin{abstract}
Summary
In order to the further development of nutrient management, adequate information on the relationships between expected yields and the nutrient level of crops are required.

The main objective of our study was to establish quantitative relationships between fertilization (applied K treatments) and plant responses (i.e. nutrient levels) of spring barley.

Our pot experiment was carried out in 2006 under greenhouse conditions in a lessivated brown forest soil (Haplic Luvisol). Malting barley (Hordeum vulgare L., Scarlett variety) was used as a test plant. Beside of the unfertilized control, 8 NPK treatment combinations were applied on two NP levels with increasing rates of K. Samples were taken at different growth stages from the main plant parts.

The highest $\mathrm{K}$ concentrations were found in young barley plants at the tillering stage and the highest value was $6.6 \% \mathrm{~K}$ resulted by the $\mathrm{N}_{2} \mathrm{P}_{2} \mathrm{~K}_{3}$ treatment. At further stages, $\mathrm{K}$ contentrations were decreased. Effects of fertilization could not result considerable differences in $\mathrm{K}$ concentration of blooming ears (ranged between $0.81-0.90 \% \mathrm{~K}$ ). Close relationships were found between $\mathrm{K}$ concentration and dry matter (DM) production. Different fertilizer treatments and ratios strongly influenced both the amounts and the quantitative distribution of $\mathrm{K}$ taken up by plants at the growth stages studied, as well as dry matter (DM) production and water content.
\end{abstract}

Key words: pot experiment, potassium fertilization, malting barley, vegetative production 


\title{
Связь обеспеченности питательными веществами, сухой массы и содержанием К растением у пивоваренного ячменя
}

\author{
А. БАЛАЖИ-К. ШАРДИ \\ Паннонский Университет Факультет Георгикон, \\ Кафедра Растениеводства и Почвоведения, Кестхей
}

\section{Резюме}

Для дальнейшего развития хозяйствования питательного вещества необходимо установить концентрации питательного элемента, показывающие как можно более надёжную связь с ожидаемым урожаем, а также хорошо характеризующие состояние упитанности растений. Известно, что калий - необходимый элемент многих жизненных процессов в жизни растений.

Цель нашей работы - найти связь между внесёнными дозами и состоянием упитанности растений.

Мы проводили наши опыты с вегетационными сосудами весной 2006 в тепличных условиях на бурой лесной почве со смывами глины. Растениями для тестирования выбрали сорт Scarlett ярового ячменя (Hordeum vulgare L.). Кроме контроля без удобрения применяли восемь доз NPK на двух уровнях NP с растущими дозами К. Мы проводили исследования в разных стадиях развития, по главным частям растения.

Самая высокая концентрация К обнаружилась в растениях во время кущения, под действием внесённых нами доз измеренная самая высокая концентрация К была $6,6 \%$, которую получили при обработке $\mathrm{N}_{2} \mathrm{P}_{2} \mathrm{~K}_{3}$. Содержание $\mathrm{K}$ цветущего колоса независимо от удобрений оказалось почти одинаковой, между $0,81-0,90 \%$. За исключением обработок $\mathrm{K}_{0}$ измеренные нами концентрации $\mathrm{K}$ попадают в удовлетворительную и высокую категорию. Результаты исследований этих связей подтверждают, что есть тесная связь между содержанием К растением и увеличением сухой массы. Обработки различными дозами и их разными пропорциями сильно влияют на то, что отдельные части растения в разных стадиях развития в каком количестве и в каком соотношении содержат принятый $\mathrm{K}$, как формируется их сухая масса, содержание влаги.

Ключевые слова: опыт с вегетационными сосудами, внесение удобрений NPK, яровой ячмень, растительный продукт 


\section{Bevezetés és irodalmi áttekintés}

A tápanyag-gazdálkodás továbbfejlesztéséhez szükséges a növények tápláltsági állapotát jól jellemzô, valamint a várható terméssel minél megbízhatóbb kapcsolatot mutató tápelem-koncentrációk megállapítása. A fiatal, bokrosodáskori növény alkalmas a tápláltsági állapot megítélésére, mert ekkor magas a tápelemkoncentráció a fiatal hajtásban (Kádár 2004). A tavaszi árpa tenyészideje rövid, gyökérzete viszonylag fejletlen, ezért víz- és tápanyagigényes növény (Wych et al. 1985).

A kálium rendkívül fontos szerepet tölt be a növények vízháztartásában, a sztómák nyitódásának-záródásának szabályozásában, javítja a fagytűrô képességet és növeli a növények stresszhelyzetekkel szembeni toleranciáját (Pethó 1993, Sárdi 1999). Sörárpa esetén ügyelni kell arra, hogy a túlzott N-trágyázás rontja a söripari minôséget, ugyanakkor a megfelelő foszfor- és káliumtrágyázás hatására javul a szárszilárdság, fokozódik a betegségekkel szembeni ellenálló képesség, növekszik a hozam, ill. a maláta, és így javul a sör minôsége is (Kádár et al. 2003).

A tápanyag- és vízellátás a növények számára létfontosságú. Ismeretes, hogy lehet bármennyi tápanyag a talajban, vízhiány esetén a növény nem tudja azokat hasznosítani és fordítva, a tápanyag-ellátottság mértéke befolyásolja a növények vízfelhasználását. A megfelelő tápanyagellátás a növények gazdaságosabb vízfelhasználását eredményezi (Debreczeni és Debreczeniné 1983). A káliummal jól ellátott növények egy adott mennyiségú szerves anyag szintézisét, illetve szárazanyag-produkciójukat kevesebb víz felhasználásával tudják biztosítani. Kálium hatására jelentôsen csökken a transzspiráció. Elsődleges szerepet játszik a sztómák nyitódásának és záródásának szabályozásában, ugyanis a sztómamozgás a legtöbb növény esetében a $\mathrm{K}^{+}$-fluxustól függ (Epstein és Bloom 2005 , Debreczeniné és Sárdi 1999).

A sörárpa átlagos NPK mútrágyaigénye: $\mathrm{N}$ : 60-80 kg/ha, $\mathrm{P}_{2} \mathrm{O}_{5}: 46 \mathrm{~kg} / \mathrm{ha}$, $\mathrm{K}_{2} \mathrm{O}: 140 \mathrm{~kg} / \mathrm{ha}$ (Kismányoky 1996).

Az egyes növényi szervek ásványanyag-felhasználása eltérő. Szárképződéskor a levelek és a szárkezdemény azonos mennyiségben tartalmazzák a káliumot. A tavaszi árpa $\mathrm{K}$ felhalmozása a vegetatív fejlődési szakaszban intenzív növekedést, a generatív szakaszban azonban fokozatos csökkenést mutat (Lásztity 2006). A virágzás utáni időszakban a szár K-tartalma kétszer nagyobb, mint a magvaké (Mészáros 1984). A szemtermés a felvett káliumnak csupán 30\%-át 
tartalmazza, míg a nagyobb része a szalmában marad (Mengel 1976). A szem relatív K-tartalma víz- és tápanyag-ellátottságtól függetlenül meglehetôsen kiegyenlített.

Jelen dolgozat célja, egyes vizsgált paraméterek (K-koncentráció, felvett K mennyiség, friss-, és száraztömeg, valamint víztartalom) változásának tanulmányozása a kálium trágyázás hatására a különböző korú növényi részekben, valamint összefüggések keresése a K koncentráció és a száraztömeg-gyarapodás között.

\section{Anyag és módszer}

Tenyészedényes kísérletünket 2006 tavaszán a Pannon Egyetem Georgikon Kar, Növénytermesztéstani és Talajtani Tanszékének üvegházában állítottuk be két eltérô talajtípuson: agyagbemosódásos barna erdőtalajon (II. termôhelyi kategória) és kötött réti talajon (III. termôhelyi kategória). Jelen dolgozatban a barna erdőtalajon végzett kísérletünket kívánjuk bemutatni, melynek főbb agrokémiai jellemzôi a következôk: $\mathrm{pH}_{\mathrm{H}_{2} \mathrm{O}}$ 6,58; humusztartalom 2,24\% (N-ellátottsága jó); $\mathrm{AL}-\mathrm{P}_{2} \mathrm{O}_{5} 50,7 \mathrm{mg} / \mathrm{kg}$ talaj (gyenge ellátottságú); $\mathrm{AL}-\mathrm{K}_{2} \mathrm{O}$ $27,5 \mathrm{mg} / \mathrm{kg}$ talaj (igen gyenge ellátottságú). Tesztnövénynek a tavaszi árpa (Hordeum vulgare L.) Scarlett fajtáját választottuk.

A trágyázatlan kontrollon kívül nyolc különböző NPK kezelést alkalmaztunk két NP szinten növekvő K-adagokkal, a sörárpa különbözô növényi részeiben történő NPK tápelem-koncentrációk változásainak tanulmányozására. Az egyes kezeléseket fejlődési stádiumonként 3 ismétlésben állítottuk be, az egyszeres hatóanyag-tartalom $\left(\mathrm{N}_{1} \mathrm{P}_{1} \mathrm{~K}_{1}\right) 60 \mathrm{mg} \mathrm{N}, 100 \mathrm{mg} \mathrm{P}_{2} \mathrm{O}_{5}$ és $140 \mathrm{mg} \mathrm{K} \mathrm{K}_{2} \mathrm{O}$ volt $1 \mathrm{~kg}$ talajban. A hatóanyagokat 27\% N-tartalmú pétisó, 16\% vízoldható $\mathrm{P}_{2} \mathrm{O}_{5}$-tartalmú szuperfoszfát, és $60 \%$-os $\mathrm{K}_{2} \mathrm{O}$-tartalmú kálisó formájában juttattuk ki. Tenyészedényenként 20 növényt neveltünk, $4 \mathrm{~kg}$ talajban, a nedvességet súlyra öntözéssel, 70\%-os vízkapacitásra állítottuk be.

A lebontások négy különbözô fejlettségi állapotban történtek: az elsô lebontás bokrosodáskor (FS: 2-3), a második lebontás a szárbaszökés végi-kalászolás eleji stádiumban (FS: 10-10.1), a harmadik lebontás teljes virágzáskor (FS: 10.5.2), a negyedik lebontás pedig teljes éréskor (FS: 11.3). A tenyészedények száma így 216 db volt ( 2 talaj $\times 9$ kezelés $\times 3$ ismétlés $\times 4$ lebontás). A mintavételezést a MÉM NAK módszer alapján végeztük (Elek és Kádár 1980). A tenyészedényben nevelt összes növény teljes föld feletti hajtása lebontásra 
került oly módon, hogy a szár vágása $1 \mathrm{~cm}$-rel a talaj felett történt. Elsố esetben az egész növény, második esetben a levél és a szár, harmadik lebontásnál a levél, szár, virágzó kalász, negyedik lebontásnál a levél, szár, kalász/termés külön kerültek vizsgálatra. Minden lebontás során mértük az átlagos növénymagasságot, a friss- és száraztömeget növényi részenként, melyből víztartalmat számítottunk. Külön növényi részenként végeztünk NPK mennyiségi analízist. A tenyészedényenkénti külön növényi részek összessége szolgált a növényminta alapjául. A növényminta kénsavas feltárása és a törzsoldat elkészítése (MSZ 081783/1 1983) után, a növényi N-tartalom meghatározása Kjeldahl módszerrel (MSZ 08-1783/6 1983), Parnass-Wagner vízgốzdesztilláló készülék segítségével, a P-koncentráció Zeiss Spekol-10 típusú spektrofotométerrel (MSZ 081783/4 1983), míg a K-koncentráció meghatározása Zeiss Flapho 4 típusú lángfotométer (MSZ 08-1783/5 1983) segítségével történt.

A statisztikai elemzés Microsoft Office Excel 2003 és 2007 számítógépes program segítségével történt.

Jelen kéziratban az agyagbemosódásos barna erdôtalajon nevelt növények elsó három lebontásból származó eredményeit kívánjuk bemutatni.

\section{Eredmények}

Korábbi publikációinkban bemutattuk, hogy a növények K tartalma megfelelően tükrözi a kiadott K adagokat, a növekvô K-trágyázás hatására szignifikáns növekedés tapasztalható a növényi K-koncentrációban. A K hiányos kezelések hatására nagymértékú csökkenés figyelhetô meg a K-tartalomban, ami a késốbbi stádiumban drasztikusabb mértékú, mint bokrosodás idején. Rendkívül szoros, pozitív összefüggés tapasztalható a növények száraztömege és a növény által felvett K mennyisége között (Balázsy és Sárdi 2006, 2008).

A három lebontásban mért K-koncentráció értékeket az 1. táblázatban szemléltetjük. A kálium trágyázás hatására szignifikáns növekedés volt tapasztalható a bokrosodáskori növények K-tartalmában. $\mathrm{N}_{1} \mathrm{P}_{1}$ szinten a $\mathrm{K}_{2}$-es kezelésnél kaptuk a legmagasabb koncentráció értékeket, míg $\mathrm{N}_{2} \mathrm{P}_{2}$ szint tekintetében a $\mathrm{K}_{3}$-as kezelés adta a legnagyobb $\mathrm{K} \%$ értékeket. $\mathrm{Az}_{2} \mathrm{P}_{2} \mathrm{~K}_{4}$-es kezelés hatására nem mutatkozott további növekedés a növények K-tartalmában. A K hiányos kezelések $\left(\mathrm{N}_{1} \mathrm{P}_{1} \mathrm{~K}_{0}\right.$ és $\left.\mathrm{N}_{2} \mathrm{P}_{2} \mathrm{~K}_{0}\right)$ esetében nagymértékben csökkent a $\mathrm{K}$ tartalom, alacsonyabb értékeket kaptunk, mint a kontrollkezelésnél. Szakirodalmi adatokkal összehasonlítva saját eredményeinket, azt kaptuk, hogy a Reuter és 
Robinson (1988) által alacsonynak ítélt 3,5-4,1\% K tartalommal megegyeznek az általunk a $\mathrm{K}$ hiányos kezeléseknél mért koncentrációk. A szerzők újabb kiadványa szerint (Reuter és Robinson 1997) azonban a kielégítónek megadott 3,8-6,2\% kategóriába a mi eredményeink is beleesnek, illetve még ennél magasabb értékeket is mértünk a nagyobb adagú kezelések esetében. Más szerzók szerint a kielégítő K tartalom bokrosodáskori árpa esetében a 4,10-6,10\% közé esik (Rama Rao és Sekhon 1987). Eredményeink szintén összhangban állnak azon megállapítással, miszerint a 2-3 hetes árpanövény K-tartalma kezelés nélkül 3,27-4,45\% körüli, míg a kezelések hatására 5,55-6,07\% között mozog (Beaton és Sekhon 1985). Az általunk kijuttatott kezelések hatására mért legmagasabb K-koncentráció 6,6\% volt.

1. táblázat. Különbözô fejlettségi stádiumban lévố növényi részek K-koncentrációjának alakulása a kezelések függvényében

\begin{tabular}{|c|c|c|c|c|c|c|}
\hline \multirow{3}{*}{$\begin{array}{l}\text { Kezelések } \\
\text { (1) }\end{array}$} & \multicolumn{6}{|c|}{$\begin{array}{c}\text { Kálium koncentráció (\%) } \\
\text { (3) }\end{array}$} \\
\hline & \multirow{2}{*}{$\begin{array}{c}\begin{array}{c}\text { I. lebontás } \\
(4)\end{array} \\
\text { Egész } \\
\text { növény } \\
(7)\end{array}$} & \multicolumn{2}{|c|}{$\begin{array}{l}\text { II. lebontás } \\
(5)\end{array}$} & \multicolumn{3}{|c|}{$\begin{array}{l}\text { III. lebontás } \\
\text { (6) }\end{array}$} \\
\hline & & $\begin{array}{l}\text { Levél } \\
(8)\end{array}$ & $\begin{array}{l}\text { Szár } \\
(9)\end{array}$ & $\begin{array}{l}\text { Levél } \\
\text { (8) }\end{array}$ & $\begin{array}{l}\text { Szár } \\
(9)\end{array}$ & $\begin{array}{c}\text { Virágzó } \\
\text { kalász } \\
\text { (10) }\end{array}$ \\
\hline $\mathrm{N}_{\mathrm{o}} \mathrm{P}_{0} \mathrm{~K}_{0}$ & 4,44 & 2,08 & 1,68 & 1,00 & 1,53 & 0,89 \\
\hline $\mathrm{N}_{1} \mathrm{P}_{1} \mathrm{~K}_{0}$ & 3,46 & 0,83 & 1,10 & 0,18 & 0,78 & 0,81 \\
\hline $\mathrm{N}_{1} \mathrm{P}_{1} \mathrm{~K}_{1}$ & 6,21 & 3,25 & 1,73 & 2,55 & 1,92 & 0,85 \\
\hline $\mathbf{N}_{1} \mathbf{P}_{1} \mathbf{K}_{2}$ & 6,43 & 4,74 & 2,11 & 4,45 & 2,83 & 0,90 \\
\hline $\mathrm{N}_{1} \mathrm{P}_{1} \mathrm{~K}_{3}$ & 5,93 & 5,31 & 2,47 & 4,95 & 3,26 & 0,87 \\
\hline $\mathbf{N}_{2} \mathbf{P}_{2} \mathbf{K}_{0}$ & 3,39 & 0,90 & 1,00 & 0,15 & 0,59 & 0,88 \\
\hline $\mathbf{N}_{2} \mathbf{P}_{2} \mathbf{K}_{2}$ & 6,34 & 4,13 & 2,54 & 3,92 & 2,46 & 0,81 \\
\hline $\mathrm{N}_{2} \mathrm{P}_{2} \mathrm{~K}_{3}$ & 6,60 & 4,97 & 3,12 & 5,44 & 3,19 & 0,87 \\
\hline $\mathbf{N}_{2} \mathbf{P}_{2} \mathbf{K}_{4}$ & 6,46 & 5,57 & 3,35 & 5,79 & 3,66 & 0,85 \\
\hline $\mathrm{SzD}_{5 \%}(2)$ & 0,40 & 0,18 & 0,22 & 0,16 & 0,26 & 0,12 \\
\hline
\end{tabular}

Table 1. K concentration of the main plant parts at different growth stages depending on NPK treatments. (1) Treatments, (2) $\mathrm{LSD}_{5 \%}$, (3) Potassium concentration (\%), (4) 1st harvest, (5) 2nd harvest, (6) 3rd harvest, (7) Whole plant, (8) Leaf, (9) Stem, (10) Blooming ear. 
A második lebontást nézve a növények K-tartalma a levélben magasabb volt, mint a szárban, kivéve a K-hiányos kezeléseket. A növekvő K adagok hatására szignifikáns növekedést figyelhetünk meg a levélben és a szárban egyaránt. A K-hiányos kezelések itt is drasztikus koncentráció csökkenést eredményeztek, az értékek alacsonyabbak, mint a kontroll kezelés esetében. Összehasonlítva eredményeinket a szakirodalomban megadott értékekkel, megállapítható, hogy az általunk kapott növényi K-tartalmak a kielégítő illetve ennél magasabb kategóriákba sorolhatók, kivéve a K hiányos kezeléseket, melyek értékei már a „hiány” kategóriába tartoznak (Bergmann és Neubert 1976, Mills és Jones 1996).

A virágzáskori árpanövény K-koncentrációját vizsgálva megállapítható, hogy valamelyest csökkent a levél K-tartalma (kivétel: $\mathrm{N}_{2} \mathrm{P}_{2}$ szinten a $\mathrm{K}_{3}$ és $\mathrm{K}_{4}$ kezelés). Szakirodalmi eredményekkel összehasonlítva saját adatainkat megállapítható, hogy a virágzási időszakban a levelek K-koncentráció értékei a $\mathrm{K}_{0}$ kezelések kivételével beleesnek a megfelelő (2,3-2,8\%), ill. magas (>2,8\%) ellátottsági kategóriába (Frageria et al. 1995). A K-hiányos kezelések kivételével a szár K-tartalma ugyanakkor növekedést mutat. A levél és a szár K-koncentrációját összehasonlítva megállapítható, hogy a K-hiányos kezelések kivételével a levélben magasabb a K-tartalom, mint a szárban. Érdekesség, hogy míg a bokrosodáskorban az $\mathrm{N}_{2} \mathrm{P}_{2} \mathrm{~K}_{4}$-es kezelés már nem eredményezett további K-tartalom növekedést, addig a késôbbi stádiumokban (II. és III. lebontásnál) a legmagasabb értékeket ennél a kezelésnél kaptuk a levélben és a szárban egyaránt.

A virágzó kalász K-koncentrációja közel kiegyenlített, nem mutat összefüggést a különbözô adagú és arányú mútrágyakezelésekkel.

A következőkben a felvett K-mennyiség, száraztömeg és víztartalom alakulását vizsgáljuk a II. és III. lebontásból származó növényi részekben a kezelések függvényében. Vizsgáljuk továbbá, hogy a kezelések milyen hatással vannak a vizsgált növényi részekben a száraztömeg, víztartalom és a növény által felvett K mennyiségi eloszlására az egész növényhez viszonyítva.

A magasabb NPK adagok hatására növekedés figyelhetô meg a növények száraztömegében, mely mindkét lebontás esetében és minden növényi részben statisztikailag igazolható a kontrollhoz képest. A két NP szint közötti száraztömeg növekedés szignifikánsnak mondható, ugyanúgy, mint a $\mathrm{K}$ hiányos kezelések hatására bekövetkezett száraztömeg csökkenés is. Legmagasabb száraztömeg értékeket az egész növény vonatkozásában II. lebontásnál az $\mathrm{N}_{2} \mathrm{P}_{2} \mathrm{~K}_{3}$ kezelésnél, a III. lebontásnál az $\mathrm{N}_{2} \mathrm{P}_{2} \mathrm{~K}_{2}$ kezelésnél kaptuk. 
A II. lebontás száraztömegének mennyiségi eloszlását tanulmányozva megállapíthatjuk, hogy a két szint eltérést mutat. Míg $\mathrm{N}_{1} \mathrm{P}_{1}$ szinten az egész növény száraztömegének kevesebb, mint 40\%-át a levél és több mint 60\%-át a szár teszi ki, addig $\mathrm{N}_{2} \mathrm{P}_{2}$ szinten a levél száraztömege nô, a száré pedig csökken. A legkiugróbb értéket az $\mathrm{N}_{2} \mathrm{P}_{2} \mathrm{~K}_{0}$ mutatja, ahol a levél száraztömege mintegy 48\%-a az egész növény száraztömegének, a száré pedig 52\%. Megállapíthatjuk, hogy a trágyázás növelésével az árpanövény levelének száraztömege nô, míg a száré csökken az egész növény viszonyításában.

A virágzáskori növény egyes részeinek száraztömeg eloszlása a kontroll kezelés esetében a következőképpen alakul: legnagyobb a virágzó kalász száraztömege, mintegy 52\%, míg a száré 29\%, legkevesebb pedig a levél száraztömege $19 \%$ az egész növényt tekintve. A tendencia a többi kezelés esetében ugyanaz, kis eltéréssel. A nagyobb mútrágyaadagot kapott növények virágzó kalászának száraztömeg mennyisége kevesebb az egész növényhez képest, míg a száré nagyobb, a levélé pedig kisebb mértékú növekedést mutat (2. táblázat).

A víztartalmat tekintve szignifikáns különbség mutatkozik a kontrollhoz képest és a két NP szint között a II. és III. lebontásnál egyaránt. A K-hiányos kezeléseknél víztartalom csökkenés következett be, mely a levél és a szár víztartalmában is mutatkozik, de a csökkenés a levélben nagyobb mértékú. A virágzó kalász víztartalma viszonylag állandó, 60\% körül mozog, nagy különbség nem mutatkozik a mútrágya kezelések hatására. $\mathrm{N}_{1} \mathrm{P}_{1}$ szinten megfigyelhető, hogy a K-adagok növelésével a virágzó kalász víztartalma fokozatosan csökken. A legmagasabb víztartalmat az $\mathrm{N}_{2} \mathrm{P}_{2} \mathrm{~K}_{0}$ kezelésú virágzó kalászban mértünk. Megállapítható, hogy az idô elôrehaladtával a növény veszít víztartalmából, az egész növényt nézve a II. lebontásnál átlagosan $80 \%$ a víztartalom, addig a III. lebontásnál a növények átlagosan 70\% vizet tartalmaznak. A III. lebontásnál a levél több mint 10\%-kal, a szár kb. 5\%-kal kevesebb vizet tartalmaz. Míg a II. lebontásnál a levelek víztartalma nagyobb, a III. lebontásnál a szár víztartalma a legmagasabb. A kezeléshatás a III. lebontásnál jobban megfigyelhetô, a K-hiányos kezelések víztartalma a legalacsonyabb az egész növényt tekintve.

A II. lebontásból származó növényi részek víztartalmának mennyiségi eloszlása jól látható különbségeket mutat a különböző mértékú trágyázások hatására. Míg a kontroll és a $\mathrm{N}_{1} \mathrm{P}_{1} \mathrm{~K}_{0}$ kezelésnél az egész növény összes víztartalmának kevesebb, mint 40\%-a található a levélben és több mint 60\% a szárban, addig a többi $\mathrm{N}_{1} \mathrm{P}_{1}$ szintú kezelés esetében ez a százalékos érték 45\% 55\%. 
BALÁZSY Á.-SÁRDI K.

2. táblázat. A vizsgált növényi részek száraztömegének (g/edény) és a száraztömeg mennyiségi eloszlásának (\%) alakulása a kezelések hatására

II. lebontás (8)

\begin{tabular}{|c|c|c|c|c|c|c|c|c|}
\hline \multirow{2}{*}{$\begin{array}{c}\text { Kezelések } \\
\text { (1) }\end{array}$} & \multicolumn{2}{|c|}{$\begin{array}{l}\text { Levél } \\
(4)\end{array}$} & \multicolumn{2}{|c|}{$\begin{array}{l}\text { Szár } \\
(5)\end{array}$} & \multicolumn{2}{|c|}{$\begin{array}{c}\text { Virágzó kalász } \\
(6)\end{array}$} & \multicolumn{2}{|c|}{$\begin{array}{c}\text { Egész növény } \\
(7)\end{array}$} \\
\hline & $\begin{array}{l}\mathrm{g} / \mathrm{e} \\
(3)\end{array}$ & $(\%)$ & $\begin{array}{l}\mathrm{g} / \mathrm{e} \\
(3)\end{array}$ & $(\%)$ & $\begin{array}{l}\mathrm{g} / \mathrm{e} \\
(3)\end{array}$ & $(\%)$ & $\begin{array}{l}\mathrm{g} / \mathrm{e} \\
(3)\end{array}$ & $(\%)$ \\
\hline $\mathrm{N}_{0} \mathrm{P}_{0} \mathrm{~K}_{0}$ & 2,9 & 35 & 5,5 & 65 & & & 8,4 & 100 \\
\hline $\mathrm{N}_{1} \mathrm{P}_{1} \mathrm{~K}_{0}$ & 6,2 & 39 & 9,7 & 61 & & & 15,9 & 100 \\
\hline $\mathbf{N}_{1} P_{1} K_{1}$ & 6,6 & 36 & 11,8 & 64 & & & 18,4 & 100 \\
\hline $\mathrm{N}_{1} \mathrm{P}_{1} \mathrm{~K}_{2}$ & 6,4 & 33 & 13,0 & 67 & & & 19,4 & 100 \\
\hline $\mathrm{N}_{1} \mathrm{P}_{1} \mathrm{~K}_{3}$ & 6,3 & 33 & 12,8 & 67 & & & 19,1 & 100 \\
\hline $\mathbf{N}_{2} \mathbf{P}_{2} \mathbf{K}_{0}$ & 7,9 & 47 & 8,8 & 53 & & & 16,7 & 100 \\
\hline $\mathbf{N}_{2} \mathbf{P}_{2} \mathbf{K}_{2}$ & 8,9 & 41 & 12,8 & 59 & & & 21,7 & 100 \\
\hline $\mathbf{N}_{2} \mathbf{P}_{2} \mathbf{K}_{3}$ & 9,3 & 42 & 12,9 & 58 & & & 22,2 & 100 \\
\hline $\mathbf{N}_{2} \mathbf{P}_{2} \mathbf{K}_{4}$ & 8,9 & 42 & 12,4 & 58 & & & 21,3 & 100 \\
\hline $\mathrm{SzD}_{5 \%}(2)$ & 0,4 & & 0,8 & & & & 1,0 & \\
\hline \multicolumn{9}{|c|}{ III. lebontás (9) } \\
\hline \multirow{2}{*}{$\begin{array}{c}\text { Kezelések } \\
\text { (1) }\end{array}$} & \multicolumn{2}{|c|}{$\begin{array}{l}\text { Levél } \\
(4)\end{array}$} & \multicolumn{2}{|c|}{$\begin{array}{l}\text { Szár } \\
(5)\end{array}$} & \multicolumn{2}{|c|}{$\begin{array}{c}\text { Virágzó kalász } \\
(6)\end{array}$} & \multicolumn{2}{|c|}{$\begin{array}{c}\text { Egész növény } \\
(7)\end{array}$} \\
\hline & $\begin{array}{l}\mathrm{g} / \mathrm{e} \\
(3)\end{array}$ & $(\%)$ & $\begin{array}{l}\mathrm{g} / \mathrm{e} \\
(3)\end{array}$ & $(\%)$ & $\begin{array}{l}\mathrm{g} / \mathrm{e} \\
(3)\end{array}$ & $(\%)$ & $\begin{array}{l}\mathrm{g} / \mathrm{e} \\
(3)\end{array}$ & $(\%)$ \\
\hline $\mathbf{N}_{\mathrm{o}} \mathrm{P}_{0} \mathrm{~K}_{0}$ & 2,8 & 19 & 4,4 & 29 & 7,7 & 52 & 14,9 & 100 \\
\hline $\mathbf{N}_{1} P_{1} K_{0}$ & 5,4 & 21 & 7,2 & 29 & 12,5 & 50 & 25,1 & 100 \\
\hline $\mathrm{N}_{1} \mathrm{P}_{1} \mathrm{~K}_{1}$ & 5,7 & 19 & 9,3 & 32 & 14,5 & 49 & 29,5 & 100 \\
\hline $\mathrm{N}_{1} \mathrm{P}_{1} \mathrm{~K}_{2}$ & 5,5 & 19 & 10,1 & 35 & 13,4 & 46 & 29,0 & 100 \\
\hline $\mathrm{N}_{1} \mathrm{P}_{1} \mathrm{~K}_{3}$ & 5,4 & 18 & 10,0 & 34 & 13,9 & 47 & 29,2 & 100 \\
\hline $\mathbf{N}_{2} \mathbf{P}_{2} \mathbf{K}_{0}$ & 7,3 & 25 & 7,3 & 25 & 14,9 & 51 & 29,5 & 100 \\
\hline $\mathbf{N}_{2} \mathbf{P}_{2} \mathbf{K}_{2}$ & 7,8 & 21 & 12,0 & 33 & 16,6 & 46 & 36,3 & 100 \\
\hline $\mathbf{N}_{2} \mathbf{P}_{2} \mathbf{K}_{3}$ & 7,9 & 22 & 13,0 & 36 & 15,2 & 42 & 36,1 & 100 \\
\hline $\mathbf{N}_{2} \mathbf{P}_{2} \mathbf{K}_{4}$ & 7,6 & 22 & 12,1 & 35 & 15,3 & 44 & 35,0 & 100 \\
\hline $\mathrm{SzD}_{5 \%}(2)$ & 0,3 & & 0,7 & & 1,1 & & 1,2 & \\
\hline
\end{tabular}

Table 2. Dry matter (DM) production ( $\left.\mathrm{g} \mathrm{pot}^{-1}\right)$ and quantitative distribution of DM production in the examined plant parts as affected by different treaments. (1) Treatments, (2) $\mathrm{LSD}_{5 \%}$, (3) g pot ${ }^{1}$, (4) Leaf, (5) Stem, (6) Blooming ear, (7) Whole plant, (8) 2nd harvest, (9) 3rd harvest. 
Ehhez képest $\mathrm{N}_{2} \mathrm{P}_{2}$ szinten a levél-szár víztartalom aránya megközelíti az 1:1 arányt, vagyis közel 50-50\%. Összességében tehát elmondható, hogy minél jobban trágyázott a növény, annál több vizet tartalmaz a levele és víztartalma a levélben és a szárban közel ugyanannyi (3. táblázat).

A trágyázás növelésével a növény víztartalmának mennyiségi eloszlása a levélben és a szárban magasabb, a virágzó kalászban pedig alacsonyabb a trágyázatlan kontrollhoz és a kevésbé táplált növényekhez képest - ez állapítható meg a virágzáskori növényi részek víztartalmának tanulmányozásakor. A virágzó kalász víztartalma az egész növényhez képest a K-hiányos kezelések $\left(\mathrm{N}_{1} \mathrm{P}_{1} \mathrm{~K}_{0}\right.$ és $\mathrm{N}_{2} \mathrm{P}_{2} \mathrm{~K}_{0}$ ) esetében a legmagasabb, mintegy 45-50\%. Az $\mathrm{N}_{2} \mathrm{P}_{2}$ szint káliumos kezeléseinél az egész növény víztartalmának 20-25\%-a a levélben, majdnem 50\%-a a szárban, és kevesebb, mint 30\%-a a virágzó kalászban található.

Rendkívül nagy szignifikáns különbségek mutatkoznak a felvett K mennyiségében mind az egész növény, mind a növényi részek tekintetében a kontrollhoz képest, mindkét lebontás esetén. A II. lebontás $K_{0}$ kezeléseinél a növény által felvett $\mathrm{K}$ a szárban több mint a levélben, a többi kezelésnél ez fordítva van. A III. lebontásnál már csak az $\mathrm{N}_{2} \mathrm{P}_{2}$ szinten a $\mathrm{K}_{2}, \mathrm{~K}_{3}$ és $\mathrm{K}_{4}$ kezelés levelében található felvett $\mathrm{K}$ több mint a szárban. A K-hiányos kezeléseknél a virágzó kalászban található felvett $\mathrm{K}$ tartalom a legmagasabb a többi növényi részhez képest, míg a többi kezelésnél ez csak a harmadik helyen áll. Szignifikáns különbség csak a kezeletlen kontroll és az $\mathrm{N}_{1} \mathrm{P}_{1} \mathrm{~K}_{0}$ kezelésnél állapítható meg. A legmagasabb értéket a virágzó kalász esetében az $\mathrm{N}_{2} \mathrm{P}_{2} \mathrm{~K}_{2}$ kezelésnél kaptuk.

A két lebontást összehasonlítva megfigyelhetô, hogy a növény által felvett $\mathrm{K}$ mennyisége a levélben az idô előrehaladtával csökken, a szárban a magasabb K-adagoknál viszont kevéssel nô $\left(\mathrm{N}_{1} \mathrm{P}_{1} \mathrm{~K}_{2}, \mathrm{~N}_{1} \mathrm{P}_{1} \mathrm{~K}_{3}, \mathrm{~N}_{2} \mathrm{P}_{2} \mathrm{~K}_{3}, \mathrm{~N}_{2} \mathrm{P}_{2} \mathrm{~K}_{4}\right)$.

A II. lebontás trágyázatlan kontrolljának esetében az összes felvett K közel 40\%-a a levélben található, 60\% pedig a szárban. Az $\mathrm{N}_{1} \mathrm{P}_{1} \mathrm{~K}_{0}$ kezelés esetében a felvett $\mathrm{K}$ mintegy $68 \%$-át a szár tartalmazza. $\mathrm{N}_{1} \mathrm{P}_{1}$ szinten a káliumos kezeléseknél megfigyelhető, hogy a felvett K 51-52\%-át tartalmazza a levél, és csupán 48-49\% található a szárban. Az $\mathrm{N}_{2} \mathrm{P}_{2}$ szint esetében a levél még több, 53-54\% felvett K-ot tartalmaz. Ez alól kivétel a K-hiányos kezelés, ahol a felvett K mennyiségének csupán 45\%-a található a levélben, és 55\%-a a szárban. Megállapítható tehát, hogy a trágyázott és K-mal jól ellátott növények felvett K-mennyiségének több mint 50\%-a a levélben található, szemben a trágyázatlan, K-hiányos növényekkel (4. táblázat). 
BALÁZSY Á.-SÁRDI K.

3. táblázat. A vizsgált növényi részek víztartalmának (\%)

és a víztartalom mennyiségi eloszlásának (\%*) alakulása a kezelések hatására

II. lebontás (7)

\begin{tabular}{|c|c|c|c|c|c|c|c|c|}
\hline \multirow[t]{2}{*}{$\begin{array}{c}\text { Kezelések } \\
\text { (1) }\end{array}$} & \multicolumn{2}{|c|}{$\begin{array}{l}\text { Levél } \\
\text { (3) }\end{array}$} & \multicolumn{2}{|c|}{$\begin{array}{l}\text { Szár } \\
\text { (4) }\end{array}$} & \multicolumn{2}{|c|}{$\begin{array}{c}\text { Virágzó kalász } \\
\text { (5) }\end{array}$} & \multicolumn{2}{|c|}{$\begin{array}{c}\text { Egész } \\
\text { növény } \\
\text { (6) }\end{array}$} \\
\hline & $\%$ & $\% *$ & $\%$ & $\% *$ & $\%$ & $\% *$ & $\%$ & $\% *$ \\
\hline $\mathrm{N}_{0} \mathrm{P}_{0} \mathrm{~K}_{0}$ & 78,9 & 36 & 77,7 & 64 & & & 78,2 & 100 \\
\hline $\mathrm{N}_{\mathrm{I}} \mathrm{P}_{1} \mathrm{~K}_{0}$ & 77,5 & 38 & 78,4 & 62 & & & 78,0 & 100 \\
\hline $\mathrm{N}_{1} \mathrm{P}_{1} \mathrm{~K}_{1}$ & 82,7 & 43 & 77,5 & 57 & & & 79,7 & 100 \\
\hline $\mathrm{N}_{1} \mathrm{P}_{1} \mathrm{~K}_{2}$ & 83,6 & 45 & 75,7 & 55 & & & 79,0 & 100 \\
\hline $\mathrm{N}_{1} \mathrm{P}_{1} \mathrm{~K}_{3}$ & 83,9 & 45 & 75,8 & 55 & & & 79,2 & 100 \\
\hline $\mathbf{N}_{2} \mathbf{P}_{2} \mathbf{K}_{0}$ & 81,4 & 49 & 80,6 & 51 & & & 81,0 & 100 \\
\hline $\mathbf{N}_{2} \mathbf{P}_{2} \mathbf{K}_{2}$ & 85,4 & 50 & 80,3 & 50 & & & 82,8 & 100 \\
\hline $\mathrm{N}_{2} \mathrm{P}_{2} \mathrm{~K}_{3}$ & 83,9 & 48 & 80,0 & 52 & & & 81,9 & 100 \\
\hline $\mathbf{N}_{2} \mathbf{P}_{2} \mathbf{K}_{4}$ & 83,7 & 48 & 79,9 & 52 & & & 81,6 & 100 \\
\hline $\mathrm{SzD}_{5 \%}(2)$ & 0,8 & & 1,6 & & & & 1,0 & \\
\hline
\end{tabular}

III. lebontás (8)

\begin{tabular}{lcccccccc}
\hline \multirow{2}{*}{\begin{tabular}{c} 
Kezelések \\
\multicolumn{1}{c}{$(1)$}
\end{tabular}} & \multicolumn{2}{c}{$\begin{array}{c}\text { Levél } \\
(3)\end{array}$} & \multicolumn{2}{c}{$\begin{array}{c}\text { Szár } \\
(4)\end{array}$} & \multicolumn{2}{c}{$\begin{array}{c}\text { Virágzó kalász } \\
(5)\end{array}$} & \multicolumn{2}{c}{$\begin{array}{c}\text { Egész } \\
\text { növény } \\
(6)\end{array}$} \\
\cline { 2 - 10 } & $\%$ & $\%^{*}$ & $\%$ & $\%^{*}$ & $\%$ & $\%^{*}$ & $\%$ & $\%^{*}$ \\
\hline $\mathrm{N}_{0} \mathrm{P}_{0} \mathrm{~K}_{0}$ & 66,4 & 19 & 72,3 & 40 & 60,3 & 41 & 65,8 & 100 \\
$\mathrm{~N}_{1} \mathrm{P}_{1} \mathrm{~K}_{0}$ & 53,8 & 17 & 63,8 & 33 & 60,3 & 50 & 60,2 & 100 \\
$\mathrm{~N}_{1} \mathrm{P}_{1} \mathrm{~K}_{1}$ & 68,7 & 21 & 73,7 & 44 & 59,0 & 35 & 66,9 & 100 \\
$\mathrm{~N}_{1} \mathrm{P}_{1} \mathrm{~K}_{2}$ & 71,0 & 21 & 75,4 & 49 & 58,3 & 30 & 68,5 & 100 \\
$\mathrm{~N}_{1} \mathrm{P}_{1} \mathrm{~K}_{3}$ & 71,6 & 21 & 76,2 & 50 & 56,3 & 28 & 68,4 & 100 \\
$\mathrm{~N}_{2} \mathrm{P}_{2} \mathrm{~K}_{0}$ & 59,0 & 19 & 73,5 & 36 & 62,7 & 45 & 65,4 & 100 \\
$\mathrm{~N}_{2} \mathrm{P}_{2} \mathrm{~K}_{2}$ & 71,7 & 25 & 74,0 & 44 & 59,5 & 31 & 68,3 & 100 \\
$\mathrm{~N}_{2} \mathrm{P}_{2} \mathrm{~K}_{3}$ & 72,9 & 25 & 75,8 & 48 & 59,5 & 27 & 70,0 & 100 \\
$\mathrm{~N}_{2} \mathrm{P}_{2} \mathrm{~K}_{4}$ & 71,0 & 22 & 77,8 & 51 & 60,0 & 27 & 70,6 & 100 \\
$\mathrm{SzD}_{5 \%}(2)$ & 2,9 & & 2,5 & & 1,6 & & 1,9 & \\
\hline
\end{tabular}

Table 3. Water content (\%) and quantitative distribution of water content $(\% *)$ in the examined plant parts as affected by different treaments. (1) Treatments, (2) LSD $5 \%$, (3) Leaf, (4) Stem, (5) Blooming ear, (6) Whole plant, (7) 2nd harvest, (8) 3rd harvest. 
4. táblázat. A vizsgált növényi részek felvett K mennyiségének (mg/edény) és a felvett K mennyiségi eloszlásának (\%) alakulása a kezelések hatására

\begin{tabular}{|c|c|c|c|c|c|c|c|c|}
\hline \multicolumn{9}{|c|}{ II. lebontás (8) } \\
\hline \multirow{2}{*}{$\begin{array}{c}\text { Kezelések } \\
\text { (1) }\end{array}$} & \multicolumn{2}{|c|}{$\begin{array}{l}\text { Levél } \\
(4)\end{array}$} & \multicolumn{2}{|c|}{$\begin{array}{l}\text { Szár } \\
(5)\end{array}$} & \multicolumn{2}{|c|}{$\begin{array}{c}\text { Virágzó kalász } \\
\text { (6) }\end{array}$} & \multicolumn{2}{|c|}{$\begin{array}{c}\text { Egész növény } \\
\text { (7) }\end{array}$} \\
\hline & $\begin{array}{c}\mathrm{mg} / \mathrm{e} \\
(3)\end{array}$ & $\%$ & $\begin{array}{c}\mathrm{mg} / \mathrm{e} \\
(3)\end{array}$ & $\%$ & $\begin{array}{c}\mathrm{mg} / \mathrm{e} \\
(3)\end{array}$ & $\%$ & $\begin{array}{c}\mathrm{mg} / \mathrm{e} \\
(3) \\
\end{array}$ & $\%$ \\
\hline $\mathbf{N}_{0} P_{0} K_{0}$ & 60,3 & 40 & 91,7 & 60 & & & 151,9 & 100 \\
\hline $\mathrm{N}_{1} \mathrm{P}_{1} \mathrm{~K}_{0}$ & 51,1 & 32 & 107,0 & 68 & & & 158,1 & 100 \\
\hline $\mathrm{N}_{1} \mathrm{P}_{1} \mathrm{~K}_{1}$ & 213,7 & 51 & 204,7 & 49 & & & 418,4 & 100 \\
\hline $\mathrm{N}_{1} \mathrm{P}_{1} \mathrm{~K}_{2}$ & 303,2 & 53 & 273,6 & 47 & & & 576,8 & 100 \\
\hline $\mathrm{N}_{1} \mathrm{P}_{1} \mathrm{~K}_{3}$ & 332,4 & 51 & 317,0 & 49 & & & 649,4 & 100 \\
\hline $\mathbf{N}_{2} \mathbf{P}_{2} \mathbf{K}_{0}$ & 71,2 & 45 & 87,5 & 55 & & & 158,7 & 100 \\
\hline $\mathrm{N}_{2} \mathrm{P}_{2} \mathrm{~K}_{2}$ & 368,1 & 53 & 325,5 & 47 & & & 693,6 & 100 \\
\hline $\mathrm{N}_{2} \mathrm{P}_{2} \mathrm{~K}_{3}$ & 460,7 & 53 & 403,3 & 47 & & & 864,0 & 100 \\
\hline $\mathbf{N}_{2} \mathbf{P}_{2} \mathbf{K}_{4}$ & 495,9 & 54 & 414,7 & 46 & & & 910,6 & 100 \\
\hline $\mathrm{SzD}_{5 \%}(2)$ & 22,5 & & 31,5 & & & & 42,0 & \\
\hline \multicolumn{9}{|c|}{ III. lebontás (9) } \\
\hline \multirow{2}{*}{$\begin{array}{c}\text { Kezelések } \\
\text { (1) }\end{array}$} & \multicolumn{2}{|c|}{$\begin{array}{c}\text { Levél } \\
(4)\end{array}$} & \multicolumn{2}{|c|}{$\begin{array}{l}\text { Szár } \\
(5)\end{array}$} & \multicolumn{2}{|c|}{$\begin{array}{c}\text { Virágzó kalász } \\
\text { (6) }\end{array}$} & \multicolumn{2}{|c|}{$\begin{array}{c}\text { Egész növény } \\
(7)\end{array}$} \\
\hline & $\begin{array}{c}\mathrm{mg} / \mathrm{e} \\
(3)\end{array}$ & $\%$ & $\begin{array}{c}\mathrm{mg} / \mathrm{e} \\
(3) \\
\end{array}$ & $\%$ & $\begin{array}{c}\mathrm{mg} / \mathrm{e} \\
(3) \\
\end{array}$ & $\%$ & $\begin{array}{c}\mathrm{mg} / \mathrm{e} \\
(3) \\
\end{array}$ & $\%$ \\
\hline $\mathrm{N}_{0} \mathrm{P}_{0} \mathrm{~K}_{0}$ & 27,8 & 17 & 66,7 & 41 & 68,7 & 42 & 163,2 & 100 \\
\hline $\mathrm{N}_{1} \mathrm{P}_{1} \mathrm{~K}_{0}$ & 9,7 & 6 & 56,1 & 34 & 101,6 & 61 & 167,4 & 100 \\
\hline $\mathrm{N}_{1} \mathrm{P}_{1} \mathrm{~K}_{1}$ & 145,3 & 32 & 178,9 & 40 & 123,0 & 27 & 447,2 & 100 \\
\hline $\mathrm{N}_{1} \mathrm{P}_{1} \mathrm{~K}_{2}$ & 245,6 & 38 & 285,0 & 44 & 120,3 & 18 & 651,0 & 100 \\
\hline $\mathrm{N}_{1} \mathrm{P}_{1} \mathrm{~K}_{3}$ & 266,5 & 37 & 325,6 & 46 & 120,5 & 17 & 712,5 & 100 \\
\hline $\mathrm{N}_{2} \mathrm{P}_{2} \mathrm{~K}_{0}$ & 10,9 & 6 & 42,9 & 23 & 131,3 & 71 & 185,0 & 100 \\
\hline $\mathrm{N}_{2} \mathrm{P}_{2} \mathrm{~K}_{2}$ & 304,8 & 42 & 295,1 & 40 & 134,2 & 18 & 734,1 & 100 \\
\hline $\mathrm{N}_{2} \mathrm{P}_{2} \mathrm{~K}_{3}$ & 427,6 & 44 & 414,9 & 43 & 132,1 & 14 & 974,6 & 100 \\
\hline $\mathbf{N}_{2} \mathbf{P}_{2} \mathbf{K}_{4}$ & 439,1 & 43 & 442,7 & 44 & 130,4 & 13 & 1012,2 & 100 \\
\hline $\mathrm{SzD}_{5 \%}(2)$ & 17,1 & & 22,4 & & 17,9 & & 34,7 & \\
\hline
\end{tabular}

Table 4. Amounts of $\mathrm{K}$ taken up by plants $\left(\mathrm{mg} \mathrm{pot}^{-1}\right)$ and its quantitavie distribution (\%) in the examined plant parts as affected by different treaments. (1) Treatments, (2) LSD $5 \%$, (3) $\mathrm{mg} \mathrm{pot}^{-1}$, (4) Leaf, (5) Stem, (6) Blooming ear, (7) Whole plant, (8) 2nd harvest, (9) 3rd harvest. 
A III. lebontás eredményeit vizsgálva megállapíthatjuk, hogy a trágyázatlan kontroll felvett K mennyiségének eloszlása az egyes növényi részekben különbözô: a levélben 17\%, a szárban 41\%, a virágzó kalászban $42 \%$ található. A K-hiányos kezeléseknél a felvett $\mathrm{K}$ összes mennyiségének csupán 6\%-át tartalmazza a levél, $\mathrm{N}_{1} \mathrm{P}_{1} \mathrm{~K}_{0}$ esetében a szárban $33 \%$, a virágzó kalászban $61 \%, \mathrm{~N}_{2} \mathrm{P}_{2} \mathrm{~K}_{0}$ esetében a szárban $23 \%$, a virágzó kalászban $71 \%$ található. A mútrágyaadagok növelésével a felvett K mennyisége a levélben eléri akár a 35-40\%-ot is, a szárban is 40-45\% körüli az érték, míg a virágzó kalászban 20\%-nál is kevesebb, az $\mathrm{N}_{2} \mathrm{P}_{2} \mathrm{~K}_{4}$ kezelés esetében csupán csak 13\%.

Az 5. táblázat adataiból megállapítható, hogy rendkívül szoros pozitív öszszefüggés van az I. lebontásból származó eredmények tekintetében a növény által felvett K illetve K-koncentráció és a növény tömeg-gyarapodása, víztartalma között, mindegyik analízis esetében.

A II. lebontás adatait nézve is hasonló eredményeket kaptunk, kivétel ez alól a felvett $\mathrm{K}$ és víztartalom közötti összefüggés az egész növényt nézve, bár a kapcsolat még így is $5 \%$ valószínúségi szinten fennáll. Nincs lineáris kapcsolat azonban a szár által felvett K és víztartalma között. Az eredmények alapján elmondhatjuk, hogy a legszorosabb összefüggés a növény levelének K koncentrációja és víztartalma között áll fenn. Nem mutat ugyanakkor kapcsolatot a levél K tartalom és száraztömeg, valamint a szár K koncentráció és víztartalom. Szár esetében a K koncentráció és a frisstömeg közötti kapcsolat a legszorosabb.

A III. lebontásból származó eredményeket nézve, rendkívül szoros kapcsolat mutatkozik az egész növény által felvett K és friss- és száraztömege között. Az egyes növényi részeket külön vizsgálva megállapíthatjuk, hogy csupán a virágzó kalász által felvett $\mathrm{K}$ és annak víztartalma között nincs összefüggés, az összes többi esetben fennáll a statisztikailag igazolható kapcsolat. Igen szoros lineáris kapcsolat található a levél és a szár K tartalma és a növényi rész produktuma között. Kivételt képez ez alól a levél K koncentráció és száraztömeg, ez esetben nincs igazolható összefüggés. Szintén nem található lineáris kapcsolat a virágzó kalász K koncentrációja és produktuma között egyik vizsgált paraméter esetében sem. 


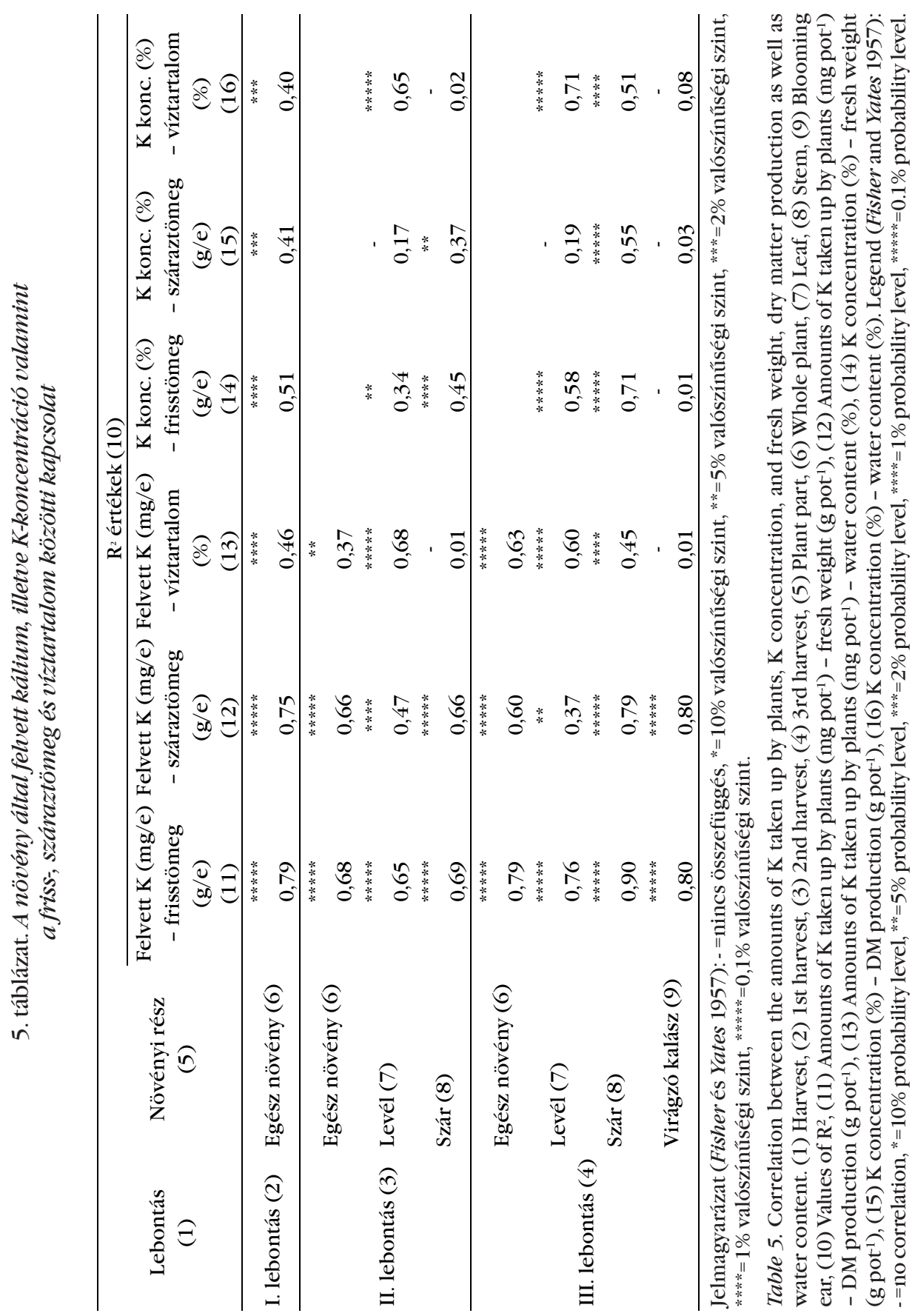




\section{Következtetések}

A legmagasabb K-koncentráció a bokrosodáskori növényekben mutatható ki, mely a késôbbi fejlettségi állapotokban csökkenést mutat. A bokrosodáskori növény K-koncentráció változása összhangban van a kijuttatott kezelésekkel, a nagyobb K-adagoknál ( $\mathrm{N}_{1} \mathrm{P}_{1} \mathrm{~K}_{3}$ és $\left.\mathrm{N}_{2} \mathrm{P}_{2} \mathrm{~K}_{4}\right)$ nem jelentkezett további koncentráció-növekedés. A II. és III. lebontásból származó levél és szár K-tartalma szoros összhangban van a kijuttatott K-adagokkal. A $\mathrm{K}_{0}$ kezelések K-koncentrációja szignifikánsan alacsonyabb a kezeletlen kontrollhoz képest. A virágzó kalász K-tartalma a trágyázástól függetlenül közel azonos, amint azt az irodalmi áttekintésben is említettük, valamint saját eredményeink is összhangban vannak ezzel az állítással - a virágzó kalász K koncentrációja a 9 kezelés esetén 0,81-0,90\% közé esik. Magyarázat lehet, hogy a növény bizonyos szintig kompenzálni tudja a nem megfelelô külsố hatásokat (pl. tápelem-hiány) és ennek megfelelôen múködik a tápelemek transzlokációja a generatív szervekbe. Ez a következtetés szintén megállapítást nyert ugyanezen kísérletünk szabadföldön végzett változatával, ahol a vizsgált eredmények nem mutattak statisztikailag igazolható összefüggést a kijuttatott mútrágyaadagok és a termés K-tartalma között (Balázsy és Sárdi 2007).

Az egész növény száraztömeg-növekedése szignifikáns különbséget mutat a kontrollhoz képest, elkülöníthető a két szint is. A virágzásban lévô egész növény száraztömege összességében növekedést mutat a II. lebontáshoz képest, a levél és a szár száraztömege azonban csökkenést. A III. lebontásban a virágzó kalász száraztömege a legnagyobb a növényi részek közül.

Összességében megállapítható, hogy a szárbaszökés végi állapotban a növény száraztömegét mintegy 60\%-ban a szár, 40\%-ban a levél teszi ki. A virágzó kalász esetében a növény száraztömegének kb. 20\%-át adja csak a levél, kb. 35\%-át a szár, legnagyobb részét pedig a virágzó kalász adja.

Az idô elôrehaladtával a növény veszít víztartalmából. Megállapítható, hogy a jobban mútrágyázott növények víztartalma magasabb, mint a kevésbé trágyázottaké. A III. lebontásnál a levél víztartalma kb. 10, a száré kb. 5\%-kal csökkent. A virágzó kalász víztartalma nem mutat nagy különbségeket, fordított arányosság áll fönn a kiadott K-adagok és a virágzó kalász víztartalma között, fôként $\mathrm{N}_{1} \mathrm{P}_{1}$ szinten. A szárbaszökés végi állapotban lévô növény levelének és szárának víztartalma közel azonos, amennyiben a magasabb szintú NPK kezeléseket nézzük. A kevesebb mútrágyát kapott és trágyázatlan kezeléseknél a növény víztartalmának több mint 60\%-a a szárban található. 
A megfelelően trágyázott virágzó állapotban lévő növény víztartalmának legnagyobb része a szárban található, míg a legkisebb mennyiséget a levél tartalmazza. K-hiányos kezelések esetében a virágzó kalász tartalmazza a legtöbb vizet.

Megállapítható, hogy a K-adagok növelésével párhuzamosan változik a növényben a felvett K eloszlása a levélben és a szárban. A növekvő K-adagok hatására a növény által felvett K egyre nagyobb része található meg a levélben és egyre kisebb a szárban. A kontrollhoz képest igencsak magasabb felvett K értékeket kaptunk a kezelések hatására. A két NP szint közötti felvett K mennyiségének növekedése szignifikánsnak mondható, ugyanúgy, mint a K hiányos kezelések hatására bekövetkezett csökkenés is.

A kezelések közötti legnagyobb változás a virágzáskori, növényi részenkénti felvett K-tartalomban mutatkozik. A trágyázatlan és K-hiányos kezelések esetében a növény felvett K-jának nagy része a virágzó kalászban található, míg a jól ellátott kezelések esetében a növény által felvett K nagy része a levélben illetve a szárban közel hasonló arányban található, a virágzó kalászban pedig elenyészô. Ebből szintén azt a következtetést vonhatjuk le, hogy hiába áll rendelkezésre nagyságrendekkel több $\mathrm{K}$, a generatív rész mégis csak korlátozott mennyiségben hasznosítja, tartalmazza.

Az összefüggés-vizsgálatok eredményei igazolják a kapcsolatot a növény Ktartalma és produktuma között. Az egész növényt nézve minden analízis pozitív kapcsolatot mutat. Ezt lebontva egyes növényi részekre megállapítható, hogy a legszorosabb összefüggés a levélben van a vizsgált paraméterek tekintetében. A virágzó kalász K-koncentrációja és a növényi produktum között nincs statisztikailag igazolható kapcsolat.

Az eredmények alapján tehát megállapítható, hogy a trágyázás nagymértékben hatással van a növény K-koncentrációjára és a növényi produktumra. Az is megállapítást nyert, hogy a különböző adagú és arányú kezelések erősen befolyásolják, hogy az egyes növényi részek mekkora mennyiségben és milyen eloszlásban tartalmaznak szárazanyagot, vizet és ásványi anyagokat (K).

Megállapításaink alátámasztásához szükségessé vált a tenyészedényes kísérletet átültetni szabadföldi körülmények közé, mely eredményeink kiértékelése feldolgozás alatt áll. 


\section{IRODALOM}

Balázsy, Á.-Sárdi, K.: 2006. Effects of variable K concentrations on the biomass production of malting barley in two different soils. IX. ESA Congress 4-7. September 2006. Warszawa. Poland. 11: 359-360.

Balázsy, Á.-Sárdi, K.: 2007. Responses of spring barley to different levels of K fertilization in a Haplic luvisol. [In: Németh, T.-Koós, S. (eds.) 10th International Symposium on Soil and Plant Analysis.] 11-15 June 2007. Budapest. Hungary. 93.

Balázsy A.-Sárdi K.: 2008. A kálium-trágyázás és a tavaszi árpa által felvett K kapcsolata üvegházi kísérletben. 2008. április 03. XIV. Ifjúsági Tudományos Fórum. Keszthely.

Beaton, J. D.-Sekhon, G. S.: 1985. Potassium Nutrition of Wheat and Other Small Grains. [In: Munson, R. D. (ed.) Potassium in Agriculture.] ASA-CSSA-SSSA. Madison. WI. USA. 31: 701-752.

Bergmann, W.-Neubert, P.: 1976. Pflanzendiagnose und Pflanzenanalyse. VEB Gustav Fischer Verlag. Jena. 490.

Debreczeni B.-Debreczeni B.-né: 1983. A tápanyag és a vízellátás kapcsolata. Mezôgazdasági Kiadó. Budapest.

Debreczeni B.-né-Sárdi K.: 1999. A tápelemek és a víz szerepe a növények életében. [In: Füleky Gy. (szerk.) Tápanyag-gazdálkodás.] Mezôgazda Kiadó. Budapest. 30-90.

Elek É.-Kádár I.: 1980. Állókultúrák és szántóföldi növények mintavételi módszere. MÉM Növényvédelmi és Agrokémiai Központ. Budapest.

Epstein, E.-Bloom, A. J.: 2005. Mineral Metabolism. [In: Mineral Nutrition of Plants: Principles and Perspectives. 2th Ed.] Sunderland. Massachusetts. USA. 8: 201-235.

Fisher, R. A.-Yates, F.: 1957. Statistical Tables for Biological, Agricultural and Medical Research. 5th Ed.] Oliver \& Boyd. London.

Frageria, N. A.-Baligar, V. C.-Jones, C. A.: 1995. Wheat and Barley. [In: Growth and Mineral Nutrition of Field Crops.] Marcel Dekker. USA. 5: 125-159.

Kádár I.: 2004. A mútrágyázás hatása a tavaszi árpa elemfelvételére karbonátos csernozjom talajon. Növénytermelés. 53. 1-2: 61-74.

Kádár I.-Béndek Gy.-Radics L.: 2003. A mútrágyázás hatása a sörárpa (Hordeum distichon) termésére és minőségére. Növénytermelés. 52. 3-4: 409-421.

Kismányoky T.: 1996. Árpa. [In: Bocz E. (szerk.) Szántóföldi növénytermesztés.] Mezôgazda Kiadó. 297-326.

Lásztity B.: 2006. Az ásványi tápelemek felhalmozása gabonafélékben. Múegyetemi Kiadó. 141-146.

Mengel K.: 1976. A növények táplálkozása és anyagcseréje. A növények táplálkozásfiziológiája. Mezőgazdasági Kiadó. 162-232.

Mészáros F.: 1984. A sörárpa fontosabb élettani-biológiai tulajdonságai, a termést alakító tényezők. [In: Lőrincz J. (szerk.) A sörárpa termesztése.] Mezőgazdasági Kiadó. 13-40. 
Mills, H. A.-Jones, J. B. Jr.: 1996. Plant Analysis Handbook II. MicroMacro Publishing. Inc. Athens. Georgia. 187.

MSZ 08-1783/1:1983: Nagy teljesítményú múszersorok alkalmazása a növényvizsgálatokban. Növényi anyagok kémiai minta-elôkészítési eljárása ásványi tápanyagok mennyiségi meghatározásához.

MSZ 08-1783/6:1983: Nagy teljesítményú múszersorok alkalmazása a növényvizsgálatokban. Növényi anyagok nitrogéntartalmának mennyiségi meghatározása.

MSZ 08-1783/4:1983: Nagy teljesítményú múszersorok alkalmazása a növényvizsgálatokban. Növényi anyagok foszfortartalmának mennyiségi meghatározása.

MSZ 08-1783/5:1983: Nagy teljesítményú múszersorok alkalmazása a növényvizsgálatokban. Növényi anyagok kálium és nátriumtartalmának mennyiségi meghatározása. Pethő M.: 1993. A növények ásványi anyag asszimilációja. [In: Pethô M. Mezőgazdasági növények élettana.] Akadémiai Kiadó. Budapest. 215-217.

Rama Rao, N.-Sekhon, G. S.: 198 7. Potassium concentration in wheat at some growth stages as an indicator for the K-status of plants. Acta Agronomica Hungarica. 36. 3-4: 203-211.

Reuter, D. J.-Robinson, J. B. (eds.): 1988. Plant Analysis. Inkata Press. Melbourne. Sydney. 40. Reuter, D. J.-Robinson, J.B. (eds.): 1997. Plant analysis. CSIRO Australia. 73-87.

Sárdi K.: 1999. A kálium szerepe a növények életében. [In: Füleky Gy. (szerk.) Tápanyaggazdálkodás.] Mezőgazda Kiadó. Budapest. 51-57.

Wych, R. D.-Simmons, S. R.-Warner, R. L.-Kirby, E.J. M.: 1985. Physiology and Development. [In: Rasmusson, D. C. (ed.) Barley.] SSSA. Madison. Wisconsin. USA. 103-125.

A szerzók levelezési címe - Address of the authors:

Balázsy Ágnes-Dr. Sárdi Katalin

Pannon Egyetem Georgikon Kar

Növénytermesztéstani és Talajtani Tanszék

Talajtani és Agrokémiai Csoport

Keszthely

Deák Ferenc u. 16.

H-8360 
